\title{
A REVIEW OF HUMAN REACTIONS TO ENVIRONMENTAL SOUNDS
}

\author{
Katarina Paunović \\ 1 Institut za higijenu sa medicinskom ekologijom, \\ Medicinski fakultet Univerziteta u Beogradu, Beograd, Srbija \\ 1 Institute of Hygiene and Medical Ecology, \\ University of Belgrade, Faculty of Medicine, Belgrade, Serbia
}

\section{SAŽETAK}

Celokupno zvučno okruženje označava se pojmom „zvučni pejzaž“ (engl. soundscape). Ovaj rad opisuje različite reakcije ljudi na zvuke u njihovoj okolini i prezentuje razvoj karakteristika tih reakcija, njihovu zastupljenost, simptome, komorbiditete, metode za procenu i moguće uzroke.

Interpretacija zvukova iz okoline zavisi, ne samo od karakteristika samog zvuka, već i od osobina slušalaca, njihovog odnosa prema zvuku i izvoru zvuka, njihove motivacije, psiholoških i emocionalnih reakcija. Tipične reakcije na zvuk predstavljene su iz dva ugla: populacione reakcije, iz ugla istraživanja u zajednici, i pojedinačne reakcije, iz ugla klinički značajnih prezentacija. Uznemirenje bukom je specifična, tipična i jedinstvena psihofiziološka reakcija na buku u životnoj sredini koja se procenjuje na nivou populacije. U osnovi uznemirenja bukom leži, između ostalog, i osetljivost na buku kao stabilna psihološka osobina. I uznemirenje bukom i osetljivost na buku igraju značajnu ulogu u razvoju drugih poremećaja zdravlja vezanih za izlaganje buci. U kliničkoj praksi pojavljuju se hiperakuzis i mizofonija kao najizraženiji načini reagovanja pojedinca na specifične zvuke u okolini. Oni mogu postati toliko izraženi da narušavaju fizičko i mentalno zdravlje individue i njeno ponašanje i funkcionisanje.

Različite reakcije ljudi na zvuke u njihovoj okolini su široko rasprostranjene i dobro proučene. Ovaj pregled literature nije samo puko definisanje pojmova u domenu psihoakustike, već može pomoći lekarima i psiholozima da in bolje razumeju. Buduća istraživanja treba usmeriti ka razvoju metoda za ublažavanje ili lečenje opisanih reakcija, kao i ka stvaranju prijatnije akustičke sredine u cilju očuvanja javnog zdravlja.

Ključne reči: zvuk, buka, psihoakustika, uznemirenje, hiperakuzis

Autor za korespondenciju:

Katarina Paunović

Institut za higijenu sa medicinskom ekologijom

Medicinski fakultet Univerziteta u Beogradu

Dr Subotića 8, 11000 Beograd, Srbija

Elektronska adresa: katarina.paunovic@med.bg.ac.rs

\section{ABSTRACT}

Soundscape is defined as the entire acoustic environment and the human responses to it. This review summarizes different human reactions to sound exposure, their development, prevalence, symptoms, comorbidities, methods for their assessment, and possible origins.

The interpretation of sounds from the environment depends, not only on the characteristics of the sound itself, but also on the characteristics of the listener, their judgments, preferences, motivations, and emotional reactions to the sound or its source. Typical sound-related reactions are presented from two standpoints: population reactions, from the community perspective, and individual reactions, from the clinical perspective. Noise annoyance is a specific, unique, and typical psychological and physiological reaction to noise, which is assessed from the community perspective. Noise sensitivity, a stable personality trait, is at the basis of noise annoyance. Both noise annoyance and noise sensitivity play important roles in the development of other noise-related health disturbances. From the clinical perspective, hyperacusis and misophonia are the most distinctive individual responses to specific sounds. They may become so pronounced that they disturb one's physical and mental health, behavior, and functioning. Human reactions to sounds in the environment are widespread and well-investigated. This review goes beyond merely defining terminology in the domain of psychoacoustics; it may help health professionals understand human reactions to sound better. Further studies need to be directed towards developing methods for alleviating or treating the described reactions, but also towards creating a more pleasant acoustic environment for the purpose of protecting public health.

Key words: sound, noise, psychoacoustics, annoyance, hyperacusis

\author{
Corresponding author: \\ Katarina Paunovic \\ Institute of Hygiene and Medical Ecology \\ Faculty of Medicine, Belgrade University \\ 8 Dr Subotića Street, 11000 Belgrade, Serbia \\ E-mail:katarina.paunovic@med.bg.ac.rs
}

Prihvaćen - Accepted: April 8, 2020; Online first: August 30, 2020. 


\section{UVOD}

Ljudi su izloženi različitim zvučnim podsticajima iz okruženja, koji se kreću od zvukova iz prirode (zvuci koje proizvode biljke, životinje, vetar, grom, kiša) do zvukova koje proizvode drugi ljudi i društvo uopšte, u šta spadaju: muzika, mašine i električni aparati, saobraćaj, industrija, gradilišta, i drugo. Zvučni pejzaž (engl. soundscape) jeste pojam koji obuhvata celokupno zvučno okruženje, kao i reakcije ljudi na njega $[1,2]$. Sam engleski termin soundscape nastao je od reči zvuk (sound) i sufiksa -scape, koji znači "vidik", odnosno „pogled na nešto”, čime se ovaj termin odnosi na celokupno viđenje ili percepciju zvukova u okruženju. Psihoakustika proučava izvore, kvalitet i karakteristike zvukova iz okruženja u odnosu na ljudske reakcije, preference, stavove i očekivanja [3].

Kvalitet zvučnog pejzaža zavisi od karakteristika zvukova koji se emituju u okviru samog okruženja, njihovog broja i frekvencije, njihove konsonance ili disonance (u zavisnosti kako ih doživljava slušalac), osećanja i kognitivnog suda koje zvuk evocira kod slušaoca, kao i od promenljivosti odnosno monotonosti zvučnog pejzaža [1]. Ravnoteža između prirodnih zvukova i saobraćajne buke mogla bi se uzeti kao indikator kvaliteta zvučnog pejzaža, kako bi se istakao nesklad između onih zvučnih izvora koji se percipiraju kao prijatni, pozitivni i blagotvorni nasuprot onih koji se smatraju nepovoljnim, negativnim, i štetnim po zvučni pejzaž [4]. Ovo je podsticaj za arhitekte i urbaniste da kreiraju prijatnije i zdravije zvučne pejzaže uklanjanjem nepoželjnih zvukova (smanjenjem saobraćaja i postavljanjem zvučnih barijera), maskiranjem neželjenih zvukova prijatnijim zvucima (npr. crvrkutom ptica ili muzikom), i uvođenjem prijatnih zvučnih i vizuelnih podsticaja u zvučni pejzaž (npr. fontana). Još uvek se traži najodrživije i najpragmatičnije rešenje za osmišljavanje zvučnog pejzaža koje bi moglo biti integrisano u dugoročno planiranje urbanih sredina $[2,4]$.

Zvuk je mehanički oscilirajući talas koji putuje od zvučnog izvora kroz vazduh, gasovitu, tečnu i čvrstu materiju, izuzimajući vakuum [5]. Percepcija zvuka prevashodno zavisi od njegovih fizičkih karakteristika, koje uključuju: zvučni pritisak (koji se izražava u paskalima $\mathrm{Pa}$ ), intenzitet zvuka (izražava se u decibelima - dB), frekvenciju (izraženu u hercima - Hz), i frekventni spektar. Ove osobine koreliraju sa psihoakustičkim karakteristikama zvuka. Na primer, percepcija glasnosti zvuka zavisi od njegovog intenziteta; oštrina zvuka je povezana sa frekvencijom; kvalitet zvuka (boja) vezana je za kopmleksnost tog zvuka, itd. Stoga, iz akustičke perspektive, ljudi doživljavaju zvukove kao glasne ili tihe, oštre ili duboke, harmonične ili disharmonične [6]. Iz psihološke perspektive, međutim, ljudi tumače zvuk kao prijatan

\section{INTRODUCTION}

Humans are exposed to various auditory stimuli from the environment, ranging from the sounds of nature (sounds made by plants, animals, wind, thunder, rain) to sounds made by other humans and society in general, which include music, mechanical and electrical equipment, traffic, industry, construction, etc. The entire acoustic environment and human responses to it are defined by the concept of soundscape [1,2]. The term soundscape is coined from the word sound and the suffix -scape, meaning "a view of something", thus referring to the overall view or the perception of sound in the environment. Psychoacoustics examines the sources, quality, and characteristics of environmental sounds in relation to human reactions, preferences, opinions, and expectations [3].

The quality of the soundscape depends on the characteristics of the sounds emitted in the environment, their number and frequencies, their consonance or dissonance (as perceived by the listener), the emotions and cognitive judgment evoked in the listener, as well as on the changeability vs. monotony of the soundscape [1]. Balance between natural sounds and traffic noise could be used as an indicator of the quality of soundscape to highlight the discrepancy between those sound sources that are perceived as favorable, positive, and restorative vs. those that are viewed as unfavorable, negative, and damaging to the soundscape [4]. This encourages architects and urban planners to create more pleasant and healthier soundscapes by eliminating unwanted sounds (i.e. reducing traffic and installing noise barriers), by masking unwanted sounds with more pleasant ones (e.g. birdsong or music), and by introducing pleasant acoustic and visual stimuli into the soundscape (e.g. water fountains). The search is still ongoing for the most sustainable and pragmatic soundscape design intervention that can be integrated into the long-term planning of urban areas $[2,4]$.

Sound is a mechanical oscillating wave travelling from the sound source through air, gas, liquid and solid matter, with the exception of vacuum [5]. The perception of sound primarily depends on its physical characteristics, which include: sound pressure (expressed in pascals - Pa), sound intensity (expressed in decibels - $\mathrm{dB}$ ), frequency (expressed in hertz $-\mathrm{Hz}$ ), and the spectrum of frequencies. These qualities correlate with the psychoacoustic properties of sound. For example, the perception of sound loudness depends on sound intensity; sound sharpness is related to its frequency; the quality of the sound (timbre) is related to its complexity, etc. Therefore, from the acoustic point of view, humans perceive sounds as loud or quiet, sharp or deep, harmonious or disharmonious [6]. From the psychological perspective, however, 
ili neprijatan, poželjan ili nepoželjan, pozitivan ili negativan, emotivno neutralan ili emotivno provokativan, značajan ili beznačajan. Sveukupna percepcija zvukova iz okruženja zavisi ne samo od osobina samih zvukova, već i od njihovog afektivnog značenja [6], kao i od sudova, preferenci i poriva slušaoca [7]. Gore navedene veze između zvuka, slušaoca i zvučnog okruženja predstavljaju predmet izučavanja naučne discipline pod nazivom psihoakustika [8].

Kako bi se pomoglo slušaocu da razume zvučni pejzaž u kontekstu svakodnevnog života, ovaj rad sažeto prikazuje različite ljudske reakcije na zvuk, njihov razvoj, zastupljenost, simptome, komorbiditete, i njihovu procenu. Negativne reakcije na zvuk su stoga prikazane iz dve perspektive: iz ugla istraživanja u zajednici, gde se uzimaju u obzir populacione reakcije na nepoželjne zvuke; i, iz ugla klinički značajnih prezentacija, gde je fokus na pojedinačnim reakcijama, koje mogu narušiti fizičko ili mentalno zdravlje pojedinca. Ovaj pregled literature može koristiti svim zdravstvenim stručnjacima kao sveobuhvatni vodič za različite prakse i naučna istraživanja u ovoj oblasti, te mogu pomoći u osmišljavanju modela za lečenje pojedinačnih pacijenata, ali i za rešavanje situacija na nivou zajednice.

\section{NEGATIVNE REAKCIJE NA ZVUK IZ UGLA ISTRAŽIVANJA U ZAJEDNICI}

Zvučno okruženje neke zajednice sastoji se prevashodno od zvukova koje emituju: saobraćaj, gradilišta, industrijska postrojenja, objekti za zabavu, sami ljudi, i životinje. Imajući u vidu negativnu percepciju takvog zvučnog pejzaža, ovi zvukovi se načelno definišu kao buka, odnosno nepoželjni zvuk [5]. Ova definicija je daleko kompleksnija nego što to izgleda na prvi pogled, zato što se oslanja isključivo na negativnu afektivnu percepciju zvuka. Ovo nadalje implicira da karakterisanje nekog zvuka kao buke zavisi, ne od samog zvuka, već od slušaoca.

Uznemirenje bukom je tipična psihološka i fiziološka reakcija na buku. Obično se opisuje kao osećanje nezadovoljstva, razdražljivosti, anksioznosti, frustracije, ili ljutine, izazvanog zvukovima iz okruženja [9]. Među svim štetnim faktorima iz okruženja, buka je jedini faktor koji izaziva uznemirenje. Opšte je poznato da uznemirenje bukom zavisi od: vrste izvora buke, karakteristika zvuka kojeg emituje izvor (intenzitet, frekvencija, boja, broj zvučnih događaja) $[9,10]$ i od prostiranja zvuka (što zavisi od građevinskog materijala, prisustva zelenila, zvučne izolacije, itd.) $[9,10,11,12]$. Uznemirenje bukom proizilazi pre svega iz osobina ličnosti, osetljivosti na buku i stavova prema konkretnim izvorima buke $[9,11]$. Uz to, uznemirenje bukom povezano je i sa kontekstom u kojem je neko izložen buci, uključujući tu i: humans interpret sound as pleasant or unpleasant, wanted or unwanted, positive or negative, emotionally neutral or emotionally provocative, meaningful or meaningless. The overall perception of the surrounding sounds depends, not only on their characteristics, but also on their affective meaning [6], as well as on the judgments, preferences, and the motivations of the listener [7]. The above-mentioned associations between the sound, the listener, and the acoustic environment present the focus of the scientific discipline called psychoacoustics [8].

In order to help readers understand soundscape in everyday life, this paper summarizes several human reactions related to sound exposure, their development, prevalence, symptoms, comorbidities, and their assessment. The adverse reactions to sound are thus presented from two standpoints: from the community perspective, which takes into account the population reactions to unwanted sounds; and from the clinical perspective, which deals with individual responses that may disturb a person's physical or mental health. This review may benefit all health professionals, as a comprehensive guide to practices and research in this field, and may help in the development of models for individual treatment and community intervention.

\section{ADVERSE REACTIONS TO SOUND FROM THE COMMUNITY PERSPECTIVE}

The sound environment of a community consists predominantly of the sounds emitted by road traffic, construction work, industrial facilities, entertainment venues, humans, and animals. Given the negative perception of such a soundscape, these sounds are generally defined as noise, i.e. unwanted sound [5]. This definition is far more complex than it seems because it relies only on negative affective perception of the sound. This further implies that the designation of a particular sound as noise depends on the listener, not on the sound itself.

Noise annoyance is a typical psychological and physiological reaction to noise. It is usually described as a feeling of displeasure, irritation, anxiety, frustration, or anger caused by environmental sounds [9]. Among all the hazardous environmental factors, noise is the only one that provokes annoyance. It is well-established that noise annoyance depends on the type of noise source, on the characteristics of the sound emitted by the source (intensity, frequency, timbre, the number of noise events) $[9,10]$, and on the propagation of the sound (which depends on construction material, presence of greenery, insulation barriers, etc.) $[9,10,11,12]$. Noise annoyance arises primarily from personality traits, noise sensitivity, and the attitudes toward particular noise sources $[9,11]$. In addition, it is related to the context of noise exposure, 
mesto gde se buka javlja (kod kuće, na poslu, u školi, itd.), uslove stanovanja (orijentacija dnevne ili spavaće sobe, spratnost, broj članova domaćinstva), vreme izloženosti buci (dnevni naspram noćnog perioda), dužinu izlaganja buci (kratkotrajno naspram dugotrajnog; kontinuirano naspram isprekidanog), kao i mere zaštite (zvučna izolacija zgrada, vrata i prozora) $[9,12]$.

Mehanizmi koji povezuju buku iz okruženja i pojavu uznemirenja dobro su utvrđeni. Buka izaziva uznemirenje time što maskira druge zvuke, remeti pažnju i koncentraciju slušaoca, povećava stepen fiziološke pobuđenosti, ili izaziva strah, a samim tim i „bori-se-ili-beži” reakcije $[13,14]$. Nevezano od toga koji je proces uključen u njih, ovi mehanizmi leže u osnovi i kratkotrajnih i dugotrajnih efekata buke [14]. Nadalje, unemirenje bukom, igra ulogu u razvoju drugih zdravstvenih ishoda povezanih sa stresom, uključujući tu i poremećaje sna, povećani krvni pritisak, glavobolje, i narušenost mentalnog zdravlja i kvaliteta života $[9,13,15]$.

Srbija je, pre deset godina, usvojila niz zakona i amandmana o zaštiti od buke u životnoj sredini, koji su obavezali vlasti da mere stepen izloženosti buci, kreiraju mape buke, te da procenjuju zastupljenost uznemirenja bukom i druge negativne efekte prisutne u populacijama izloženim buci [16]. U pilot studiji, koju je sprovela opština Stari grad u Beogradu, više od trećine svih odraslih ispitanika iskazala je visok stepen uznemirenja saobraćajnom bukom [17]. Iznenađuje to što je procenat ljudi koji su pokazali visoki stepen uznemirenja bukom, a koji je zabeležen u ovom terenskom istraživanju, prevazišao teorijske procene za 10 do $20 \%$, za sve nivoe buke [17]. Ovaj fenomen poznat je kao tolerancija na nivou zajednice, i on opisuje raskorak između epidemioloških i teorijskih procena uznemirenja bukom u populaciji [18]. Tolerancija na nivou zajednice prepoznaje uticaj gore navedenih ne-akustičkih faktora koji izazivaju uznemirenje bukom iz različitih izvora i kod različitih populacija [18].

Evropska agencija za životnu sredinu je nedavno procenila da 22 miliona ljudi širom Evrope pati od hroničnog visokog uznemirenja usled dugotrajne izloženosti buci [19]. Najnovije meta-analize takođe potvrđuju vezu: izloženost - reakcija, između buke iz različitih saobraćajnih izvora i procenta ljudi sa visokim stepenom uznemirenja bukom, što je utvrđeno u više različitih studija [20]. Imajući u vidu sve štetne efekte buke, Svetska zdravstvena organizacija rangirala je saobraćajnu buku kao drugi po redu faktor rizika po ljudsko zdravlje u Zapadnoj Evropi, iza zagađenosti vazduha [19].

Uznemirenje bukom može se lako proceniti primenom dva standardizovana upitnika sa standardizovanim skalama odgovora (tzv. verbalne i numeričke skale), koje preporučuje Međunarodna komisija o biološkim efektima buke (engl. International Commission on Biological including the place of exposure (home, work, school, etc.), housing conditions (orientation of the living room or bedroom, floor level, crowding), the time of exposure (daytime vs. nighttime), the duration of exposure (shortterm vs. long-term; continuous vs. intermittent), and protective measures (insulation of the buildings, doors, and windows) $[9,12]$.

The mechanisms linking environmental noise and the occurrence of annoyance are well known. Noise causes annoyance by masking other sounds, interrupting the attention and focus of the listener, increasing the level of physiological arousal, or by provoking fear and consequent fight-or-flight reactions $[13,14]$. Regardless of the process involved, these mechanisms account for both the short-term and the long-term effects of noise [14]. Furthermore, noise annoyance plays a role in the development of other stress-related health outcomes, including sleep disturbances, increased blood pressure, headaches, and impaired mental health and quality of life $[9,13,15]$.

A decade ago, Serbia adopted a set of laws and amendments on the protection from environmental noise, which required authorities to measure noise exposure, create noise maps, and assess the prevalence of noise annoyance and other adverse effects in the exposed populations [16]. In a pilot study carried out in the municipality of Stari Grad, in Belgrade, more than a third of all adult responders were highly annoyed by road traffic noise [17]. Surprisingly, the proportion of highly annoyed persons reported in this field research exceeded theoretical estimations by $10-20 \%$, for all noise levels [17]. This phenomenon is known as the community tolerance level, depicting the discrepancy between the epidemiological and the theoretical assessments of noise annoyance in the community [18]. The community tolerance level recognizes the impact of the above-mentioned non-acoustic factors that cause noise annoyance from different sources and in different populations [18].

The European Environment Agency recently estimated that 22 million people across Europe suffer from chronic high annoyance due to prolonged noise exposure [19]. The latest meta-analyses also confirm the exposure - response association between noise from different traffic sources and the proportion of highly annoyed persons, across studies [20]. Bearing in mind all the harmful effects of noise, the World Health Organization ranked traffic noise as the second risk factor for human health in Western Europe, after outdoor air pollution [19].

Noise annoyance can easily be assessed using two standardized questionnaires with standardized response scales (so-called verbal and numerical scales), as recommended by the International Commission on 
Effects of Noise - ICBEN) [21], a koje je usvojila Međunardona organizacija za standardizaciju (engl. International Standardization Organization- ISO) (ISO/TS 15666) [22]. Od ispitanika se traži da iskažu u kojoj meri su bili uznemireni (onespokojeni, iznervirani) bukom u svojem domu, koja je dopirala iz određenog izvora, tokom prethodnih 12 meseci. Obe skale su uspešno primenjene prilikom terenskih istraživanja sprovedenih u Beogradu [11,12].

Međutim, ljudske reakcije na buku iz okruženja obično prevazilaze prosto uznemirenje. Umesto "tihe patnje" ili sklanjanja u tiše okruženje, neki ljudi su izražavali svoje stavove prema buci u formi besa, agresije, verbalnih prigovora, pa čak i fizičkog konflikta. Javni prigovori na buku se shvataju ozbiljno u mnogim zemljama i uključuju se u zakonsku regulativu o buci, kako bi lokalne vlasti mogle da primene odgovarajuće mere $u$ rešavanju problema sa bukom. Jedna anketa o prigovorima na buku, objavljena na društvenim mrežama, ukazuje na to da žitelji najčešće protestuju protiv komšijske buke, saobraćajne buke sa ulice, buke koja dopire iz objekata za zabavu, i buke sa gradilišta [23]. Nameće se zaključak da su građani koji se žale uznemireniji bukom nego oni koji se ne žale, ali, potrebno je dalje istražiti povezanost između pojedinačnih pritužbi i stepena uznemirenja na nivou zajednice [24].

Kao što je već objašnjeno, uznemirenje bukom proističe iz akustičkih i ne-akustičkih faktora. Jedan od potonjih jeste osetljivost pojedinca na buku. Osetljivost na buku može se razumeti kao skup fizioloških, psiholoških ili osobina ličnosti vezanih za način života, koje odslikavaju opšte stavove pojedinca prema buci u svakodnevnim životnim situacijama $[25,26]$. Osetljivost na buku igra značajnu ulogu u pojavi uznemirenja bukom $[12,27]$. Nadalje, visoka osetljivost na buku povezana je sa kardiovaskularnim oboljenjima [28], lošim fizičkim i mentalnim zdravljem [29], kao i visokim stepenom percepirane anksioznosti i depresije [30].

Još uvek se istražuje neurološka, anatomska i fiziološka osnova osetljivosti na buku; rezultati bi trebalo, ne samo da pomognu naučnicima da je razumeju, već i da ukažu na mogućnosti objektivnog merenja ove osobine ličnosti [31]. U ovom trenutku, subjektivna osetljivost na zvuk se procenjuje uz pomoć Vajnštajnove skale osetljivosti na buku (engl. Weinstein's Noise Sensitivity Scale) [32]. Ovo je najstarija (osmišljena je 1978.), najduža i najkompleksnija skala u ovoj disciplini, koja se sastoji od 21 pitanja. Svako pitanje iziskuje od ispitanika da iskaže svoje stavove o buci, u raznim situacijama, kao i da razume svoje emocionalne reakcije na niz različitih zvukova [32]. Uprkos pokušajima da se skala redukuje, kako bi oduzimala manje vremena ispitanicima i bila jednostavnija za obradu istraživačima, još uvek je u širokoj upotrebi, uključujući tu i studije sprovedene u Beogradu [11,12,30].
Biological Effects of Noise (ICBEN) [21], and adopted by the International Standardization Organization (ISO/TS 15666) [22]. The respondents are asked to report the extent to which they have been annoyed (disturbed, bothered) by noise from a specific source in their home, in the previous 12 months. Both scales were successfully applied in field studies conducted in Belgrade [11,12].

However, human reactions to environmental noise often go further than mere annoyance. Rather than "suffering in silence" or seeking quieter acoustical surroundings, some persons expressed their attitudes toward noise in the form of anger, aggression, verbal complaints, and even physical conflict. Public complaints of noise are taken seriously in many countries and are included in noise legislation, so that the local authorities can apply adequate measures to resolve the noise problem. A survey of noise complaints reported on online social networks indicates that residents most often protest against neighborhood noise, traffic noise in the streets, noise from entertainment venues, and noise from construction sites [23]. It seems reasonable to conclude that the residents who complain are more annoyed than the non-complainers, but the link between individual complaints and the community annoyance level deserves to be explored further [24].

As explained above, noise annoyance arises from acoustic and non-acoustic factors. One of the latter is the individual's sensitivity to noise. Noise sensitivity can be understood as a cluster of physiological, psychological, or lifestyle-related personality traits, which portray one's general attitudes toward noise in everyday situations $[25,26]$. Noise sensitivity plays an important role in the occurrence of noise annoyance $[12,27]$. Furthermore, high noise sensitivity is associated with cardiovascular diseases [28], poor physical and mental health [29], and high perceived anxiety and depression [30].

The neurological, anatomical, and physiological basis of noise sensitivity is currently under investigation; the findings should not merely help researchers better understand it, but also suggest the possibilities for objective measurement of this personality trait [31]. Currently, subjective noise sensitivity is assessed with Weinstein's Noise Sensitivity Scale [32]. This is the oldest (developed in 1978), the longest and the most complex scale in this discipline, consisting of 21 items. Each item requires the respondents to report their attitudes toward noise in various situations, and to understand their emotional reactions to a variety of sounds [32]. In spite of the attempts to reduce this scale, to make it less time-consuming for the participants and simpler to process for the researches, it is still widely in use, including the studies performed in Belgrade $[11,12,30]$. 


\section{NEGATIVNE REAKCIJE NA ZVUK IZ UGLA KLINIČKI ZNAČAJNIH PREZENTACIJA}

Negativna reakcija na zvuke iz okruženja se generalno definiše kao smanjena tolerancija na zvuk, odnosno negativna reakcija na zvučne podsticaje koji ne bi izazvali istu reakciju kod prosečnog slušaoca [33]. Najčešća vrsta smanjene tolerancije na zvuk u kliničkom okruženju jeste hiperakuzis. Hiperakuzis (engl. hyperacusis) se odnosi na negativne reakcije na fizičke karakteristike zvuka, kao što su intenzitet (glasnost) ili frekvencija (oštrina) zvuka, nezavisno od izvora, konteksta, ili značenja zvučnog podsticaja [33]. Ovaj naziv potiče od prefiksa hiper-, što znači „previše", i grčkog korena reči -akuzis, što znači „slušna sposobnost", odnosno "čujenje“. Osoba sa hiperakuzisom obično ima problema sa obavljanjem misaonih aktivnosti (čitanje, koncentracija) u glasnim okruženjima, ne može lako da zanemari zvukove u svakodnevnim situacijama, i ne oseća se prijatno u društvenim situacijama gde je izložena glasnoj muzici i ljudskim glasovima (objekti za zabavu, društvena okupljanja, i sl.) [34].

Svi ovi emocionalni, kognitivni i bihejvioralni aspekti inkorporirani su u upitnik o hiperakuzisu, koji je osmišljen 2002. godine [34]. Zastupljenost hiperakuzisa kreće se u opsegu od $8 \%$ do $17 \%$ u različitim populacijama, u zavisnosti od uzrasta učesnika i primenjenih kriterijuma [35]. Etiologija hiperakuzisa je i dalje nepoznata. Ipak, može se povezati sa nekoliko oboljenja, uključujući tinitus, glavobolje, povrede glave, autizam, mijasteniju gravis, lajmsku bolest, Adisonovu bolest, i dr. [36]. Takođe je poznato da osobe sa hiperakuzisom mogu pokazati viši nivo neuroticizma, depresije, anksioznosti, impulsivnosti, agresije, i drugih osobina ličnosti [35].

Još jedan psihološki fenomen uočen u kliničkoj praksi jeste mizofonija, koja se definiše kao abnormalno snažna emocionalna i ponašajna reakcija na vrlo konkretne zvuke, nevezano od njihovih fizičkih karakteristika [33]. Reč mizofonija potiče od prefiksa mizo-, što znači "mrzeti", i reči fonija, što znači „zvuk". Stoga se ona pravilno prevodi kao "mržnja prema zvuku". Karakteristična slika mizofonije jeste da osoba koja od nje pati iskazuje snažnu uznemirenost, iritaciju ili ljutinu kada je izložena zvucima - okidačima, kao što su zvuci disanja, žvakanja, gutanja, coktanja, pročišćavanja grla, pljuvanja, i sl. [37]. Ovi provocirajući zvuci obavezno moraju poticati od druge osobe (ne i od same osobe koja pati od mizofonije), moraju izazivati izraženu nelagodnost i neprijatnost, moraju uzrokovati agresivnu reakciju kod osobe sa ovim poremećajem, moraju osobu dovesti do toga da verbalno i fizički protestuje protiv izvora zvuka, ili je naterati da se povuče iz date socijalne situacije $[33,37,38]$.

Simptomi mizofonije procenjuju se primenom Amsterdamske skale mizofonije (Amsterdam Misophonia

\section{ADVERSE REACTIONS TO SOUND FROM THE CLINICAL PERSPECTIVE}

A negative reaction to environmental sounds is generally defined as decreased sound tolerance, i.e. an adverse reaction to auditory stimuli that would not evoke the same response in an average listener [33]. The most common type of decreased sound tolerance in a clinical setting is hyperacusis. Hyperacusis refers to negative reactions to the physical characteristics of sound, such as intensity (loudness) or sound frequency (sharpness), independently of the source, the context, or the meaning of the stimulus [33]. The term comes from the prefix hyper-, meaning "excessive", and the Greek root acusis, meaning "ability to hear". Typically, a person with hyperacusis has trouble performing mental activities (reading, concentrating) in loud environments, cannot easily ignore sounds in everyday situations, and does not feel at ease in social situations where he or she is exposed to loud music and voices (entertainment venues, social receptions, etc.) [34].

All these emotional, cognitive and behavioral aspects are incorporated into a hyperacusis questionnaire constructed in 2002 [34]. The prevalence of hyperacusis ranges from $8 \%$ to $17 \%$ in different populations, depending on the age of the participants and the criteria applied [35]. The etiology of hyperacusis remains unknown. Yet, it can be associated with several diseases, including tinnitus, headache, head injury, autism, myasthenia gravis, Lyme disease, Addison's disease, etc. [36]. It is also known that persons with hyperacusis may exhibit higher levels of neuroticism, depression, anxiety, impulsiveness, aggression, and other personality traits [35].

Another psychological phenomenon observed in clinical practice is misophonia, defined as an abnormally strong emotional and behavioral reaction to very specific sounds, independent of their physical characteristics [33]. Misophonia comes from the prefix miso-, meaning "to hate", and the word phonia, meaning "sound". It is, therefore, correctly translated as the "hatred of sound". Typically, a person with misophonia expresses strong distress, irritation or anger when exposed to triggering sounds, such as the sounds of breathing, chewing, swallowing, lip smacking, throat clearing, spitting, etc. [37]. These provoking sounds must come from other humans (not from the suffering persons themselves), must cause excessive discomfort and distress, must cause an aggressive reaction by the suffering person, must cause them to verbally or physically protest against the source of the sounds, or force them to withdraw from the social situation $[33,37,38]$.

Misophonia symptoms are assessed using the Amsterdam Misophonia Scale (A-MISO-S), developed in 2013 [38]. This questionnaire requires an interview 
Scale - A-MISO-S) koja je nastala 2013. godine [38]. Ovaj upitnik iziskuje intervju koji sprovodi obučeni profesionalac, koji ne samo da mora da postavlja pitanja o konkretnim simptomima, već mora i da proceni njihov intenzitet kod ispitanika. Zastupljenost mizofonije $u$ opštoj populaciji je oko 3\%, ali bi mogla biti značajno veća među pacijentima sa hiperakuzisom [37]. Baš kao i hiperakuzis, mizofonija je često povezana sa anksioznošću, depresijom, i drugim psihološkim poremećajima [33]. Stoga postoje sukobljena mišljenja oko toga da li je opravdano da se mizofonija prepoznaje, dijagnostikuje i leči kao odvojen psihijatrijski poremećaj [37,38].

\section{VIŠE OD TERMINOLOGIJE}

Ukratko, razlikujemo nekoliko negativnih reakcija na zvuke iz okoline. Međutim, opisi nekih od ovih reakcija se međusobno preklapaju i mogu navoditi na pogrešne zaključke u svakodnevnoj komunikaciji, ne samo među laicima, već i među zdravstvenim stručnjacima. Na primer, postoji intenzivna rasprava o terminologiji koja se koristi da se opišu hiperakuzis, fonofobija, mizofonija, i uznemirenje bukom [36]. Istraživači su stavili primedbe da se isti termini često koriste da opišu različite senzacije, te da se različiti termini često koriste da opišu slične senzacije. Stoga je neophodno da se gleda šire od same terminologije u ovoj disciplini, i da se pruže jednostavne, nedvosmislene i sveobuhvatne definicije za sve zdravstvene ishode vezane za zvuk, koje mogu razumeti, tumačiti, i shvatiti i stručnjaci ali i opšta populacija [36].

Negativne reakcije na zvuk, međutim, možda predstavljaju samo vrh ledenog brega u ovoj naučnoj oblasti. Negativne reakcije na svakodnevne faktore iz životne sredine sežu šire od osetljivosti na zvuk, i uključuju i osetljivost na taktilne podsticaje, hemikalije sa snažnim mirisom, kao i osetljivost na elektromagnetna polja [39]. Nevezano od vrste osetljivosti, osoba koja pati od datog poremećaja doživljava čitav niz nespecifičnih simptoma koji nemaju medicinsku podlogu [40]. Imajući u vidu sličnosti među simptomima i njihovu psihofiziološku podlogu, predloženi zajednički termin za sve ove osetljivosti jeste idiopatska netolerancija na okruženje $[39,40]$. Buduća istraživanja trebalo bi da se usredsrede na dijagnostičke kriterijume i alate za procenu različitih tipova netolerancija na okruženje, kao i na izučavanje njihove etiologije, posledica, i mogućnosti lečenja. Ovo bi trebalo da dovede do kreiranja pozitivnijih i prijatnijih životnih sredina, kao i do unapređenja javnog zdravlja uopšte.

\section{ZAKLJUČAK}

Ovaj pregled opisuje karakteristike nekoliko reakcija vezanih za izlaganje zvuku. One uključuju uznemirenje zvukom, kao najizraženiju reakciju, iz ugla istraživanja u with a trained professional, who not only has to make inquiries about the specific symptoms, but also assess their intensity in the respondent. The prevalence of misophonia in the general population is about 3\%, but it could be much higher among patients with hyperacusis [37]. Just like hyperacusis, misophonia is often associated with anxiety, depression, and other psychological disorders [33]. Therefore, there is much debate whether misophonia should be recognized, diagnosed, and treated as a separate psychiatric disorder $[37,38]$.

\section{BEYOND THE TERMINOLOGY}

To summarize, several adverse reactions to environmental sounds can be distinguished. However, the descriptions of some of these reactions overlap and are possibly misleading in everyday communication, not only among laypersons, but among health professionals as well. For example, there is a wide discussion on the terminology used to describe hyperacusis, phonophobia, misophonia, and noise annoyance [36]. Researchers have commented on the fact that the same terms tend to be used to describe different sensations, and that different terms are often used to describe similar sensations. Thus, it is necessary to look beyond the vocabulary in this discipline, and to provide simple, unambiguous and comprehensive definitions of all sound-related health outcomes, which can be understood, interpreted and appreciated by both professionals and the general public [36].

Adverse reactions to sound, however, may only represent the tip of the iceberg in this scientific area. Adverse reactions to everyday environmental factors go beyond sensitivity to sounds, and include sensitivity to tactile stimuli, odorous chemicals, and electromagnetic fields [39]. Regardless of the type of sensitivity, the suffering person presents with a series of non-specific symptoms, without medical justification [40]. Given the similarities in the symptoms and their psychophysiological background, the proposed common term for all these sensitivities is idiopathic environmental intolerance $[39,40]$. Future research should focus on the diagnostic criteria and the assessment tools for various types of environmental intolerances, and the exploration of their etiology, consequences, and treatment possibilities. This should lead to the development of more positive and friendly environments, and to the improvement of public health in general.

\section{CONCLUSION}

This review elaborates the characteristics of several reactions related to sound exposure. They include noise annoyance, as the most prominent reaction from the 
zajednici, i hiperakuzis i mizofoniju, kao jedinstvene fenomene, iz ugla klinički značajnih prezentacija. Ove reakcije predstavljene su i analizirane zajedno sa osetljivošću na zvuk, što je osobina ličnosti ključna za reakcije uznemirenja zvukom. Zdravstveni stručnjaci trebalo bi da se usredsrede na osmišljavanje mogućih načina lečenja ljudi koji pate od ovih reakcija vezanih za zvuk. Svi koji deluju u oblasti javnog zdravlja suočeni su sa izazovom uvođenja trajnih mera u zajednici koje će promovisati i garantovati zvučna okruženja visokog kvaliteta.

Izjava zahvalnosti: Autorka zahvaljuje svojim prijateljicama i koleginicama, prof. dr Sanji Milenkovići i prof. dr Neli Puškaš, sa Medicinskog fakulteta u Beogradu, koje su je inspirisale svojim idejama i podstakle da napiše ovaj pregled literature.

Sukob interesa: Nije prijavljen.

\section{LITERATURA / REFERENCES}

1. Davies WJ, Adams MD, Bruce NS, Cain R, Carlyle A, Cusack P, et al. Perception of soundscapes: An interdisciplinary approach. Appl Acoust. 2013; 74:224-31.

2. Kang J, Aletta F, Gjestland TT, Brown LA, Botteldooren D, Schulte-Fortkamp $B$, et al. Ten questions on the soundscapes of the built environment. Build Environ. 2016; 108:284-94.

3. Engel MS, Fiebig A, Pfaffenbach C, Fels J. A review of socio-acoustic surveys for soundscape studies. Current Pollution Reports. 2018; 4:220-39.

4. Kogan P, Arenas JP, Bermejo F, Hinalaf M, Turra B. A Green Soundscape Index (GSI): The potential of assessing the perceived balance between natural sound and traffic noise. Sci Total Environ. 2018; 642:463-72.

5. Belojević G, Paunović K. Buka u životnoj sredini. In: Vasiljević N. Praktikum iz higijene sa medicinskom ekologijom za studente medicine. Beograd: Medicinski fakultet Univerziteta u Beogradu. 2019; 77-84.

6. Västfälll D. Emotional reactions to sounds without meaning. Psychology. 2012; 3:606-9.

7. Gomez $P$, Danuser B. Affective and physiological responses to environmental noises and music. Int J Psychophysiol. 2004; 53(2):91-103.

8. Fiebig A. The perception of acoustic environments and how humans form overall noise assessments. Proceedings of the INTER-NOISE 2019. 49th International Congress and Exposition on Noise Control Engineering. Noise Control for a Better Environment. 2019 Jun 16-19, Madrid, Spain. ISSN 0105175x. ISBN 978-84-87985-31-7. Available from: http://www.sea-acustica.es/ fileadmin/INTERNOISE_2019/Enter.htm.

9. Ouis D. Annoyance from road traffic noise: a review. J Environ Psychol. 2001; 21:101-20.

10. Raggam RB, Cik M, Höldrich RR, Fallast K, Gallasch E, Fend M, et al. Personal noise ranking of road traffic: subjective estimation versus physiological parameters under laboratory conditions. Int J Hyg Environ Health. 2007; 210:97-105.

11. Paunovic K, Jakovljevic B, Belojevic G. Predictors of noise annoyance in noisy and quiet urban streets. Sci Total Environ, 2009; 407(12):3707-11.

12. Jakovljevic B, Paunovic K, Belojevic G. Road-traffic noise and factors influencing noise annoyance in an urban population. Environ Int. 2009; 35(3):552-6.

13. Rylander R. Physiological aspects of noise-induced stress and annoyance. J Sound Vib. 2004; 277:471-8. community perspective, and hyperacusis and misophonia, as unique phenomena, from the clinical perspective. These reactions are presented and discussed together with noise sensitivity - a cornerstone personality trait for annoyance reactions. Health professionals should focus on the development of treatment options for persons suffering from these sound-related reactions. Everyone in the public health domain faces the challenging task of introducing permanent community measures that will promote and guarantee high-quality sound environments.

Acknowledgements: The author is grateful to her friends and colleagues, Prof. Sanja Milenković and Prof. Nela Puškaš from the Faculty of Medicine, University of Belgrade, who inspired her with ideas and encouraged her to write this review.

Conflict of interest: None declared.

14. Miedema HME. Annoyance caused by environmental noise: elements for evidence-based noise policies. J Social Issues. 2007; 63(1):41-57.

15. Clark C, Paunovic K. WHO Environmental noise guidelines for the European Region: A systematic review on environmental noise and quality of life, wellbeing and mental health. Int J Environ Res Public Health. 2018; 15(11):2400.

16. Ordinance on noise indicators, limits, methods for evaluating indicators of noise, annoyance and adverse effects of environmental noise. Official Gazette of the Republic of Serbia. 2010:75/2010.

17. Paunović K. Uznemiravanje bukom kod odraslog gradskog stanovništva raskorak između teorije i prakse. Acta Medica Medianae. 2013; 52(3):12-7.

18. Schomer P, Mestre V, Fidell S, Berry B, Gjestland T, Vallet M, et al. Role of community tolerance level (CTL) in predicting the prevalence of the annoyance of road and rail noise. J Acoust Soc Am. 2012; 131(4):2772-86.

19. European Environment Agency. Environmental noise in Europe - 2020. EEA Report No 22/2019. Available at: https://www.eea.europa.eu/publications/ environmental-noise-in-europe.

20. Guski R, Schreckenberg D, Schuemer R. WHO Environmental noise guidelines for the European Region: A systematic review on environmental noise and annoyance. Int J Environ Res Public Health. 2017; 14(12):1539.

21. Fields JM, de Jong RG, Gjestland T, Flindell IH, Job R, Kurra S, et al. Standardized general-purpose noise reaction questions for community noise surveys: Research and a recommendation. J Sound Vib. 2001; 242:641-79.

22. International Standardization Organization. ISO TS 15666 . Technical specification: Acoustics - Assessment of noise annoyance by means of social and socio acoustic surveys. 2003.

23. Gasco L, Clavel C, Asensio C, de Arcas G. Beyond sound level monitoring: Exploitation of social media to gather citizens' subjective response to noise. Sci Total Environ. 2019; 658:69-79.

24. Nykaza ET, Hodgdon KK, Gaugler T, Krecker P, Luz GA. On the relationship between blast noise complaints and community annoyance. J Acoust Soc Am. 2013; 133(5):2690-8.

25. Job RFS. Noise sensitivity as a factor influencing human reactions to noise. Noise Health. 1999; 3:57-68.

26. Miedema HME, Vos H. Noise sensitivity and reactions to noise and other environmental conditions. J Acoust Soc Am. 2003; 113(3):1492-504. 
27. Fyhri A, Klæboe R. Road traffic noise, sensitivity, annoyance and self-reported health - a structural equation model exercise. Environ Int. 2009; 35:91-7.

28. Heinonen-Guzejev M, Vuorinen HS, Mussalo-Rauhamaa H, Heikkilä K, Koskenvuo $M$, Kaprio J. The association of noise sensitivity with coronary heart and cardiovascular mortality among Finnish adults. Sci Total Environ. 2007; 372(2-3):406-12.

29. Hill EM, Billington R, Krägeloh C. Noise sensitivity and diminished health: Testing moderators and mediators of the relationship. Noise Health. 2014; 16(68):47-56.

30. Milenković S, Paunović K. Noise sensitivity, handedness, and the occurrence of high perceived anxiety and depression in young adults. Pers Individ Diff. 2015; 83:158-63.

31. Kliuchko $M$, Puoliväli $T$, Heinonen-Guzejev $M$, Tervaniemi $M$, Toiviainen $P$, Sams $M$, et al. Neuroanatomical substrate of noise sensitivity. Neuro Image. 2018; 167:309-15.

32. Weinstein ND. Individual differences in relation to noise: a longitudinal study in a college dormitory. J Appl Psychol. 1978; 63:458-66.

33. Jastreboff PJ, Jastreboff MM. Decreased sound tolerance: hyperacusis, misophonia, diplacousis, and polyacousis. Handb Clin Neurol. 2015; 29:375-87.
A REVIEW OF HUMAN REACTIONS TO ENVIRONMENTAL SOUNDS

34. Khalfa S, Dubal S, Veuillet E, Perez-Diaz F, Jouvent R, Collet L. Psychometric normalization of a hyperacusis questionnaire. ORL J Otorhinolaryngol Relat Spec. 2002; 64(6):436-42.

35. Jüris L, Andersson G, Larsen HC, Ekselius L. Psychiatric comorbidity and personality traits in patients with hyperacusis. Int J Audiol. 2013; 52(4):230-5.

36. Tyler RS, Pienkowski M, Roncancio ER, Jun HJ, Brozoski T, Dauman N, et al. A review of hyperacusis and future directions: Part I. Definitions and manifestations. Am J Audiol. 2014; 23(4):402-19.

37. Taylor S. Misophonia: A new mental disorder? Med Hypotheses. 2017; 103:109-17.

38. Schröder A, Vulink N, Denys D. Misophonia: diagnostic criteria for a new psychiatric disorder. PLOS ONE. 2013; 8:e54706.

39. Nordin S, Karvala K, Nyback M-H, Sainio M. Prevalence of environmental annoyance in a Swedish and Finnish general population: Impact of everyday exposures on affect and behavior. J Environ Psychol. 2018; 56:84-90.

40. Palmquist E, Claeson A-S, Neely G, Stenberg B, Nordin S. Overlap in prevalence between various types of environmental intolerance. Int J Hyg Environ Health. 2014; 217(4-5):427-34. 